\title{
Aplikasi Tuning Metode Cohen-Coon pada Pengendali pH di Tangki Netralisasi, Unit Pengolahan Limbah
}

\section{Application of Cohen-Coon Method for Tuning of pH Controller Parameters in Neutralization Tank, Waste Water Treatment Unit}

\author{
Profiyanti H. Suharti ${ }^{a^{*}}$, Khalimatus Sa'diyah a , M. Rizky Hernanda a and Rania Mirantika Sarida ${ }^{\text {a }}$ \\ ${ }^{a}$ Politeknik Negeri Malang, Jl. Soekarno Hatta 9, Malang, 65141, Indonesia
}

\section{Artikel histori : \\ Diterima 27 April 2019 Diterima dalam revisi 31 Juli 2019 Diterima 24 Oktober 2019} Online 31 Oktober 2019

\begin{abstract}
ABSTRAK: Air limbah yang dihasilkan dalam industri harus diolah terlebih dahulu, untuk memenuhi standar yang ditetapkan oleh Pemerintah. $\mathrm{pH}$ menjadi parameter penting dalam proses pengolahan air limbah. Seperti pada limbah industri serat sintetis mengandung ion yang membuat $\mathrm{pH}$ air limbah berkisar 2 hingga 3. Nilai ambang batas untuk pH air limbah, berdasarkan peraturan Menteri lingkungan, berkisar antara 6 hingga 9. Proses utama untuk mencapai standar ini adalah proses netralisasi. Pengontrol $\mathrm{pH}$ telah dipasang untuk memantau dan memenuhi target $\mathrm{pH}$ di tangki netralisasi. Pengontrol $\mathrm{pH}$ yang digunakan adalah jenis pengontrol PID (proporsional, integral, derivatif). Parameter PID yang digunakan dalam controller adalah proporsional gain $(\mathrm{Kc})=10$, waktu integral $=(\tau \mathrm{i}) 1$ menit dan waktu derivative $\left(\tau_{\mathrm{D}}\right)=10$ detik. Parameter ini menghasilkan respons osilatif. Penelitian ini bertujuan untuk mendapatkan parameter PID optimal yang dapat diterapkan dalam IPAL sehingga pH air limbah bisa dikontrol pada kisaran $\mathrm{pH}$ 7. Hasil percobaan menunjukkan bahwa parameter pengontrol PID $\mathrm{Kc}=0,251, \tau \mathrm{i}=151 \mathrm{detik}=2,51$ menit dan $\tau_{\mathrm{D}}=12,5$ detik, memiliki kinerja yang lebih baik daripada parameter pengontrol PID yang digunakan sebelumnya.

Kata kunci: proporsional; integral; derivatif; tangki; netralisasi
\end{abstract}

\begin{abstract}
Wastewater generated in industry should be treated, in order to meet the standards set by the Government. $\mathrm{pH}$ became important parameters in the process of wastewater treatment. One of waste in industrial synthetic fibers contain ions that make pH of wastewater ranged from 2 to 3. The value of the threshold for the $\mathrm{pH}$ of the wastewater, based on regulation of the Minister of environment, ranged from 6 to 9. The main process to achieve this standar was the neutralization process. In order to fulfilment the $\mathrm{pH}$ target, $\mathrm{pH}$ controller has been used to monitor the $\mathrm{pH}$ at neutralization tank. $\mathrm{pH}$ controller which is used is a type of PID (proportional, integral, derivative) controller. The PID parameter that used in the controller are proportional gain (Kc) 10, integral time ( $\tau i) 1$ minutes and 10 second as derivative time $\left(\tau_{D}\right)$. This parameter yields an oscillation response. This research aims to get the optimum PID parameters that can be applied to keep wastewater $\mathrm{pH}$ around 7. The experiment results show that the parameters of the PID controller $K c=0.251, \tau i=151$ second $=2.51$ minutes and $\tau_{D}=12.5$ second, had better performance than the PID controller parameters used previously.
\end{abstract}

Keywords: proportional; integral; derivative; neutralization; tank

\section{Pendahuluan}

Air limbah yang dihasilkan dalam industri harus diolah terlebih dahulu, untuk memenuhi standar yang ditetapkan oleh Pemerintah. $\mathrm{pH}$ menjadi parameter penting dalam proses pengolahan air limbah. Salah satu limbah dalam industri serat sintetis mengandung ion-ion sulfida, seperti $\mathrm{H}_{2} \mathrm{~S}, \mathrm{CS}_{2}, \mathrm{~S}^{2-}$, yang membuat $\mathrm{pH}$ air limbah berkisar antara 2 hingga 3. Nilai ambang batas untuk pH air limbah, berdasarkan Peraturan Kementrian Lingkungan Hidup
Republik Indonesia Nomor 5 Tahun 2014 tentang Baku Mutu Air Limbah, berkisar antara 6 hingga 9. Proses utama untuk mencapai standar ini adalah proses netralisasi. Untuk memenuhi target $\mathrm{pH}$, pengontrol $\mathrm{pH}$ telah digunakan untuk memantau $\mathrm{pH}$ di tangki netralisasi. Pengontrol $\mathrm{pH}$ yang digunakan adalah jenis pengontrol PID (proportional, integral, and derivatieve controller).

Proses netralisasi berlangsung di tangki netralisasi (neutralization unit) yaitu di mana limbah (influent) yang

*Corresponding Author: +62-8121748083; fax : +62-341404424

Email: profiyanti@polinema.ac.id 
berasal dari unit proses mengalami proses penetralan dengan penambahan kapur (lime) di pH tank. Proses tersebut terlihat dalam Gambar 1. Penambahan kapur dilakukan berdasarkan hasil pengukuran $\mathrm{pH}$ di dalam $\mathrm{pH}$ tank, dan tergantung pada besarnya persen bukaan control valve. Dengan demikian, variabel-variabel dalam sistem pengendali ini berupa: (1) process variable - PV, atau dikenal juga sebagai controlled variable, adalah $\mathrm{pH}$ larutan limbah di dalam $\mathrm{pH}$ tank; (2) manipulated variable - MV adalah laju alir kapur yang ditambahkan ke dalam $\mathrm{pH}$ tank; dan (3) disturbance - D adalah laju alir limbah yang masuk $\mathrm{pH}$ tank (influent). Laju alir kapur yang ditambahkan ke dalam $\mathrm{pH}$ tank diatur dengan mengubah bukaan control valve, yang bekerja secara otomatis mengikuti PID Controller berdasarkan nilai error

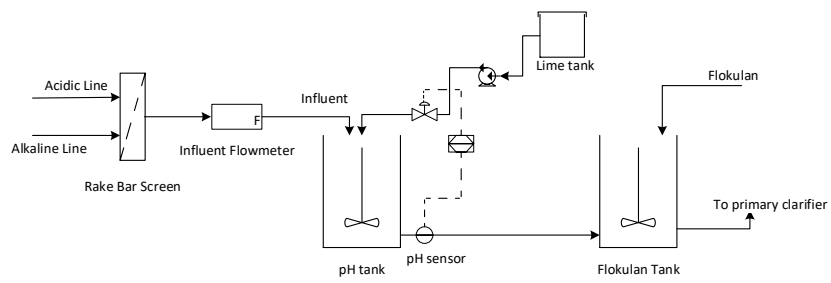

Gambar 1. Neutralization unit QIC 3001 di waste water treatment plant industri serat sintetis

(selisih antara $\mathrm{pH}$ larutan limbah terukur aktual di $\mathrm{pH}$ tank dan $\mathrm{pH}$ larutan limbah yang diinginkan - set point).

Parameter PID yang digunakan dalam PID controller di unit ini adalah proportional band $(\mathrm{PB}) 10$, integral time $(\tau \mathrm{i})$ 1 menit dan 10 detik sebagai derivative time $\left(\tau_{\mathrm{D}}\right)$. Parameter ini menghasilkan respons osilatif, seperti tersaji di Gambar 2. Pengendali PID sebetulnya memberikan respon yang positif apabila diaplikasikan dalam pengendali $\mathrm{pH}$. (Kumar \& Deepika, 2014) menyebutkan bahwa aplikasi pengendali PID pada pengendali $\mathrm{pH}$ pada proses netralisasi limbah tekstil memberikan nilai integral absolute error (IAE) yang kecil. (Wahid \& Abdillah, 2014) juga mengaplikasikan pengendali PID untuk pengendalian $\mathrm{pH}$ limbah cair laboratorium Departemen Teknik Kimia UI dengan kesimpulan yang sama.

Penelitian ini bertujuan untuk mendapatkan parameter PID optimal, di mana ketika diaplikasikan di unit netralisasi QIC 3001 tidak diperoleh respon yang osilatif. Penentuan parameter PID dilakukan dengan metode kurva reaksi (reaction curve method - Cohen Coon method), seperti dilakukan Babu dan Swarnalath (2017) ketika melakukan PID tuning di proses netralisasi limbah industri tekstil. (Hermawan, 2010) telah menggunakan metode kurva reaksi dalam menentukan parameter PID untuk tuning pada pengendali suhu dari pemanas tangki berpengaduk. Begitu juga Hermawan dan Haryono (2012) yang mempelajari dinamika komposisi larutan dalam mixing tank. Penggunaan metode kurva reaksi dalam kedua proses tersebut menghasilkan respon yang baik dengan osilasi dan offset yang kecil.

\section{Metode Penelitian}

Penelitian ini dilakukan dalam beberapa tahapan, yaitu: (1) penentuan karakteristik komponen pengendali, penentuan fungsi hantar proses, (3) validasi fungsi hantar proses, (4) penentuan parameter pengendali (tuning) dan (5) analisa hasil tuning. Sistem pengendali $\mathrm{pH}$ di tangki netralisasi (QIC 3001) memiliki diagram blok seperti tersaji di Gambar 3. Komponen pengendali dalam sistem tersebut meliputi sensor $(\mathrm{Gm})$, control valve $(\mathrm{Gv})$, controller $(\mathrm{Gc})$ dan proses pencampuran asam basa di tangki netralisasi (Gp).

Penentuan karakteristik komponen pengendali, baik sensor maupun control valve, serta penentuan fungsi hantar proses dilakukan menggunakan metoda kurva reaksi. Metoda kurva reaksi diperoleh ketika pengendali dalam mo-

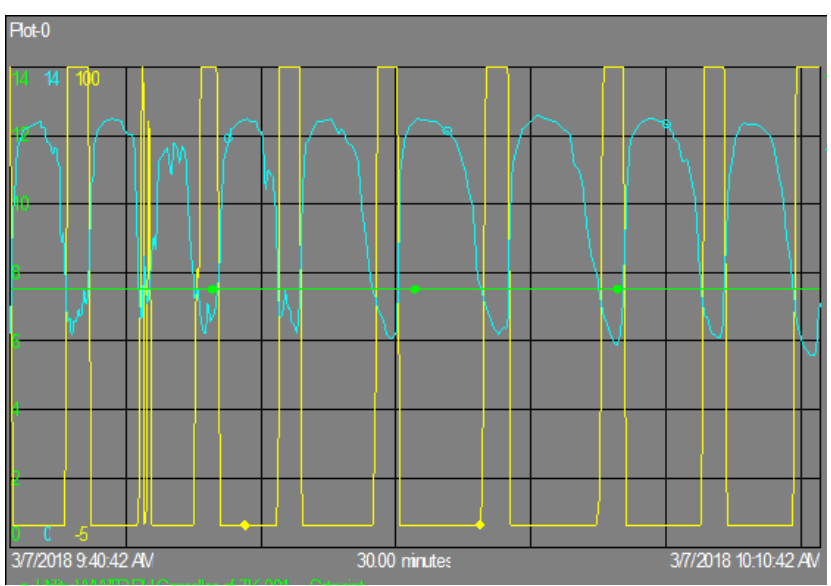

Gambar 2. Kinerja dari PID controller QIC 3001 Keterangan: (sumber: data recording industri serat sintetis, 2018)

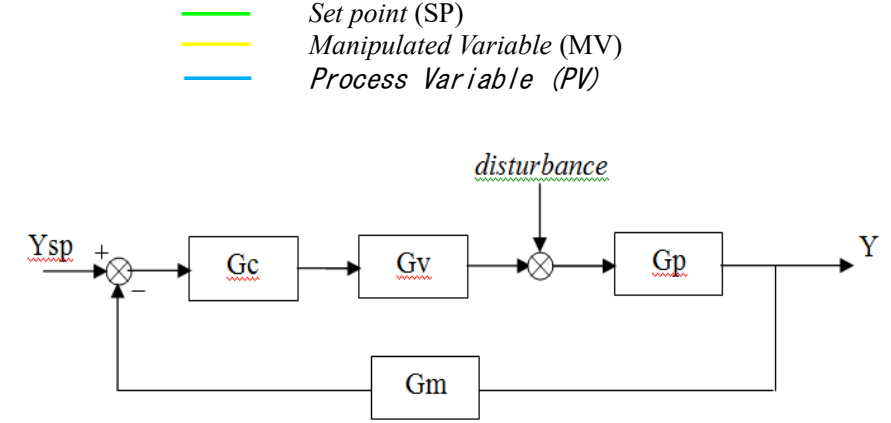

Gambar 3. Diagram blok logika proses di neutralization unit QIC 3001

de manual dan ditunggu sampai PV mencapai nilai konstan tertentu (steady state). Selanjutnya diberikan perubahan input berupa fungsi step (step test) dan dilakukan pengamatan hingga diperoleh nilai konstan berikutnya. Kurva yang diperoleh disebut kurva reaksi. Penentuan karakter sensor menggunakan buffer $\mathrm{pH} 7$ dan kemudian secara mendadak sensor dipindahkan ke buffer pH 10. Sedangkan untuk karakter proses dilakukan dengan memberikan perubahan nilai persen bukaan valve dengan variabel perubahan sebesar $-6 \%,-4 \%,-2 \%,+2 \%,+4 \%,+6 \%$ dari nilai kondisi steady state. Selanjutnya dilakukan identifikasi parameter fungsi transfer menggunakan hasil step test.

Pengendali $\mathrm{pH}$ di tangki netralisasi QIC 3001 dapat dimodelkan sebagai first order process plus dead time 
(FOPDT), dengan persamaan umum dalam bentuk fungsi laplace mengunakan persamaan (1), di mana: Gp adalah fungsi hantar proses, $\mathrm{Kp}$ adalah process gain, $\tau_{\mathrm{p}}$ adalah time constant process dan td adalah dead time atau waktu keterlambatan respon proses.

$$
G_{P}=\frac{K_{P}}{\tau_{P} s} e^{-t_{d} s}
$$

Validasi fungsi hantar proses dilakukan dengan membandingkan kurva fungsi hantar yang diperoleh dari hasil perhitungan dengan kurva reaksi selama eksperimen untuk masing-masing variabel perubahan tersebut di atas. Penentuan parameter pengendali (tuning) dilakukan dengan metoda kurva reaksi, atau dikenal juga dengan istilah metode Cohen - Coon untuk perubahan set point (servo system). Persamaan yang digunakan dalam tuning metoda Cohen Coon merupakan persamaan tuning untuk pengendali PID, di mana parameter Kc (proportional gain), ti (integral time) dan $\tau_{\mathrm{D}}$ (derivative time) memiliki nilai. Penggunaan ketiga parameter tersebut mengacu pada penelitian Babu and Swarnalath (2017). Persamaan yang digunakan tersaji di tabel 1.

Tabel 1. Persamaan tuning dengan Metoda Cohen - Coon

\begin{tabular}{|c|c|}
\hline $\mathrm{K}_{\mathrm{c}}$ (proportional band) & $K_{c}=\frac{1}{K_{p}} \frac{\tau_{p}}{t_{d}}\left(\frac{4}{3}+\frac{t_{d}}{4 \cdot \tau_{p}}\right)$ \\
\hline$\tau_{\mathrm{i}}($ integral time $)$ & $\tau_{i}=t_{d} \frac{32+6 \cdot t_{d} / \tau_{p}}{13+8 \cdot t_{d} / \tau_{p}}$ \\
\hline$\tau_{\mathrm{D}}($ derivative time $)$ & $\tau_{D}=t_{d} \frac{4}{11+2 \cdot t_{d} / \tau_{p}}$ \\
\hline
\end{tabular}

Tahapan terakhir dari penelitian ini adalah analisa respon dari penerapan parameter tuning. Analisa respon dilakukan dengan membandingkan performa masing-masing respon. Performa respon ditunjukkan dengan nilai parameter period of oscillation, overshoot dan sum square of error (SSE). Nilai SSE diperoleh dari persamaan berikut:

$$
(S S E)=\sum_{i=1}^{n}\left(y_{i}-y_{s p}\right)^{2}
$$

\section{Hasil dan Pembahasan}

Diagram blok sistem pengendali proses $\mathrm{pH}$ pada Neutralization unit dapat dilihat pada Gambar 3. Sistem tersebut merupakan sistem pengendali close loop (lup tertutup) karena adanya umpan balik dari proses yang terjadi. $Y_{\mathrm{sp}}$ merupakan istilah yang digunakan untuk mengambarkan set point $\mathrm{pH}$ yang ditentukan pada plant yaitu pada $\mathrm{pH}$ 8. $\mathrm{Y}_{\mathrm{sp}}$ dibandingkan dengan hasil pengukuran blok Gm (measurement) dan menjadi masukan bagi blok Gc (controller). Gc memberikan respon ke Gv (blok valve). Setelah itu, disturbance (berupa laju alir influent) mempengaruhi keluaran (output) dari $\mathrm{Gv}$ dan menjadi masukan bagi blok Gp (blok proses). Keluaran blok Gp (Y) adalah output dari rangkaian sistem pengendali. Apabila Y belum sama dengan set point $\left(\mathrm{Y}_{\mathrm{sp}}\right)$ maka diumpanbalikkan ke awal proses untuk dilakukan pengaturan kembali agar sesuai set point yang diharapkan.

\subsection{Karakteristik sensor}

Penentuan karakteristik sensor dilakukan dengan memberi perubahan secara mendadak ke sensor $\mathrm{pH}$. Perubahan yang dilakukan adalah dengan mencelupkan sensor $\mathrm{pH}$ ke dalam larutan buffer $\mathrm{pH} 7$ dan buffer $\mathrm{pH}$ 10. Hasil rekaman data pembacaan tahapan karakteristik sensor disajikan dalam Gambar 4. Gambar tersebut menunjukkan bahwa respon (hasil pembacaan) membentuk fungsi step, dengan besaran yang sama seperti perubahan input yang dilakukan, yaitu dari buffer $\mathrm{pH} 7$ ke buffer $\mathrm{pH}$ 10. Ketika sensor dicelupkan ke buffer pH 10 pembacaan pada Distributed Control System (DCS) masih berkisar mendekati 10 sedangkan ketika sensor dicelupkan ke buffer pH 7 pembacaan sensor juga berkisar antara $\mathrm{pH}$ 7. Dengan demikian, fungsi hantar untuk sensor pH di unit QIC 3001 hanya berupa gain dengan nilai sebesar 1 karena respon menunjukkan kurva yang sama dengan perubahan input (perubahan nilai $\mathrm{pH}$ ) yang diberikan.

Tahapan berikutnya adalah penentuan karakteristik control valve. control valve dalam sistem QIC 3001 diasumsikan linear karena tidak memungkinkan untuk pengambilan data. Karakteristik control valve yang linear menunjukkan bahwa persen bukaan valve berbanding lurus dengan laju alir manipulated variable yang dihasilkan. Selain itu, perubahan terhadap control valve menghasilkan respon yang sama dengan inputan. Dengan demikian, fungsi hantar untuk control valve diasumsikan juga berupa gain dengan nilai 1 .

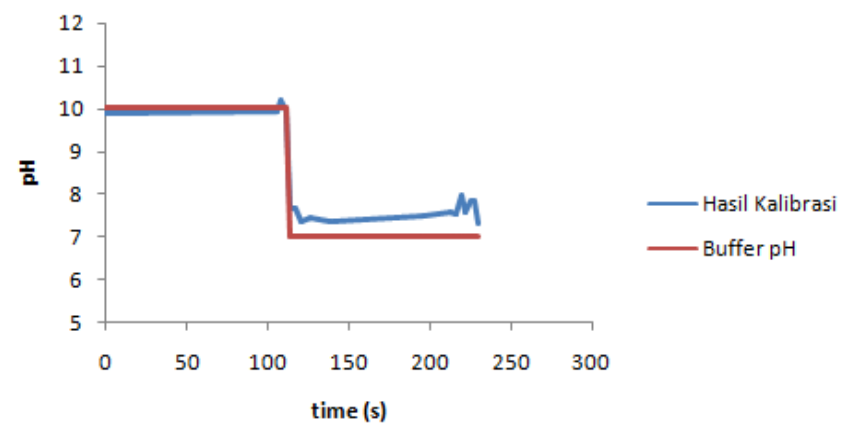

Gambar 4. Kurva respon karakteristik sensor pH di unit QIC 3001

\subsection{Karakteristik proses}

Karakteristik proses dinyatakan dalam bentuk fungsi hantar (transfer function) proses. Penentuan fungsi hantar proses dilakukan dengan menggunakan step test. Step test dilakukan pada beberapa perubahan persen bukaan valve (\%PO), yaitu: $+6 \%,-6 \%,+4 \%,-4 \%,-2 \%$, dan $+2 \%$, Hasil step test untuk masing-masing perubahan disajikan di Gambar 5. Berdasarkan kurva tersebut dilakukan penentuan fungsi hantar dari masing-masing perubahan, yang disajikan dalam Tabel 2. Semua variabel menunjukkan kecenderungan yang sama yaitu mengikuti karakter first order process plus dead time (FOPDT). 
Hasil step test, yang tersaji di Gambar 5 dan Tabel 2 menunjukkan bahwa kondisi steady state awal untuk masing-masing variabel berbeda. Eksperimen sudah diupayakan menggunakan persen bukaan valve yang sama, sekitar 20\% persen bukaan, dengan harapan diperoleh kondisi steady state awal (PV1) yang hampir sama. Akan tetapi kondisi di plant berbeda. Kondisi steady state awal ini dipengaruhi oleh kondisi influent tangki netralisasi, berupa air limbah dari unit proses, yang berubah-ubah $\mathrm{pH}$ nya. Perbedaan tersebut dicoba diminimalisasi dengan mencari nilai PV1 yang hampir mendekati.

Smuts (2011) menyatakan bahwa semakin besar nilai perubahan \%PO maka nilai dead time $\left(\mathrm{t}_{\mathrm{d}}\right)$ semakin kecil dan sebaliknya nilai time constant process $\left(\tau_{\mathrm{p}}\right)$ naik seiring dengan bertambahnya nilai perubahan \%PO. Kondisi ini tidak sesuai dengan hasil eksperimen.

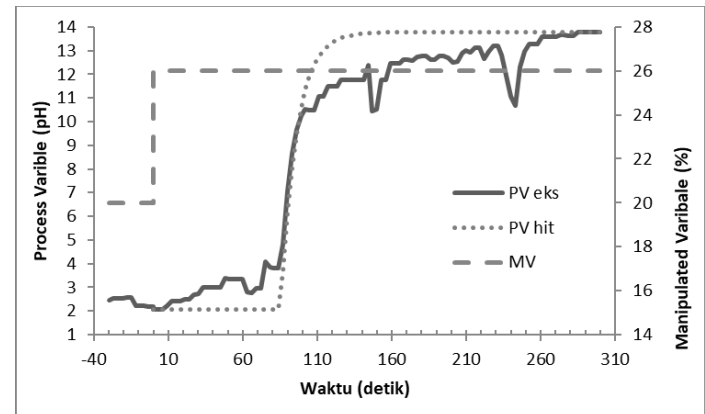

(a)

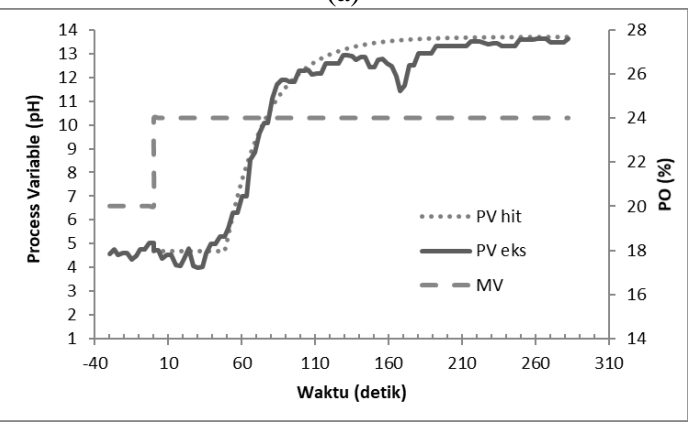

(b)

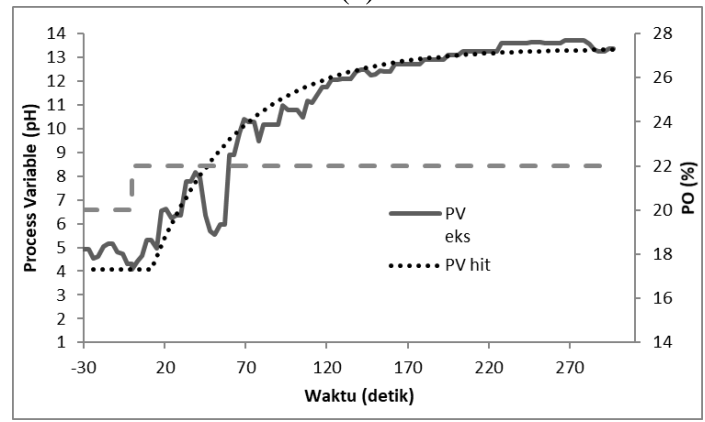

(c)

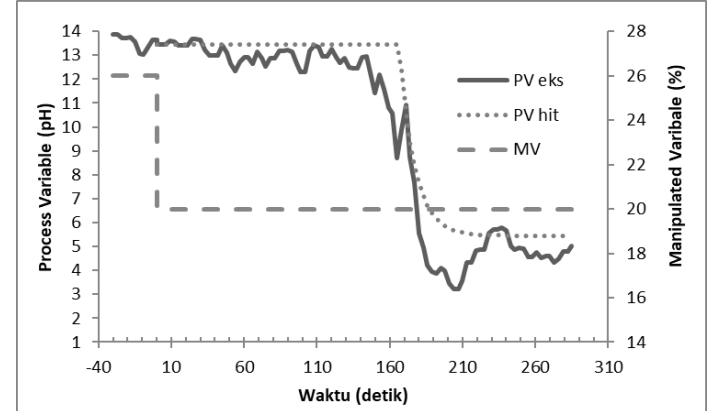

(d)

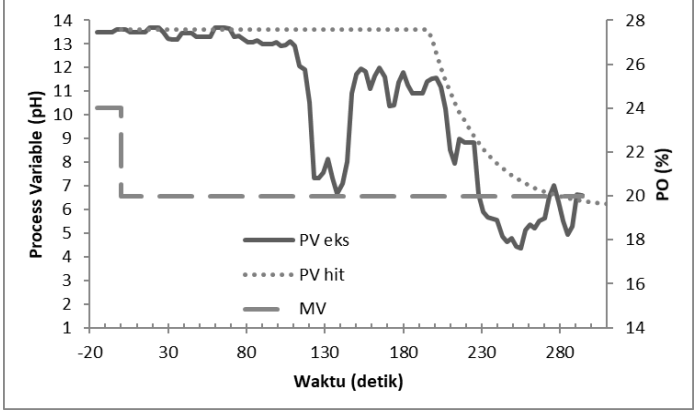

(e)

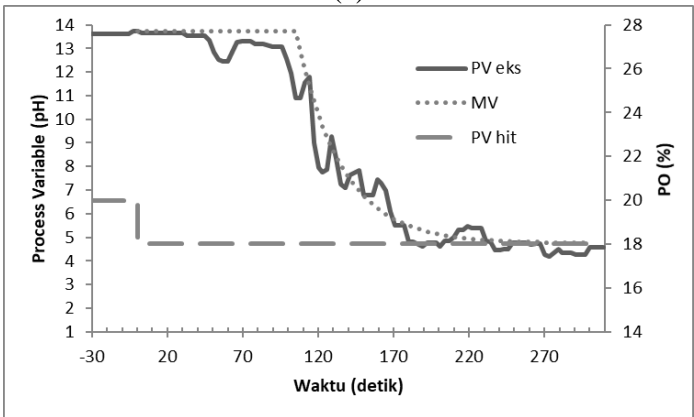

(f)

Gambar 5. Hasil Percobaan Penentuan Karakteristik Proses (Penentuan Fungsi Hantar untuk Masing-masing Perubahan \%PO; (a) $+6 \%$, (b) $-6 \%$, (c) $+4 \%$, (d) $-4 \%$, (e) $+2 \%$ dan (f) $-2 \%$.

Tabel 2. Fungsi Hantar untuk Masing-masing Perubahan \%PO

\begin{tabular}{lccl}
\hline $\begin{array}{c}\text { Gambar } \\
\text { No. }\end{array}$ & $\begin{array}{c}\text { Perubahan } \\
\text { \%PO }\end{array}$ & $\begin{array}{c}\text { Perubahan } \\
\text { PV }(\mathbf{p H})\end{array}$ & Fungsi hantar \\
\hline 5. (a) & $20-26(+6 \%)$ & $2,45-13,63$ & $\frac{1,95}{10,5 s+1} e^{-85,5 s}$ \\
5. (b) & $20-24(+4 \%)$ & $4,55-13,62$ & $\frac{2,25}{28,5 s+1} e^{-48,5,5 s}$ \\
5. (c) & $20-22(+2 \%)$ & $4,73-13,38$ & $\frac{4,66}{54,6 s+1} e^{-11,62 s}$ \\
5. (d) & $26-20(-6 \%)$ & $13,79-5,01$ & $\frac{1,33}{10,5 s+1} e^{-166,5 s}$ \\
5. (e) & $24-20(-4 \%)$ & $13,59-6,58$ & $\frac{1,90}{31,5 s+1} e^{-196,5 s}$ \\
5. (f) & $20-18(-2 \%)$ & $13,75-4,57$ & $\frac{4,5}{30 s+1} e^{-105 s}$ \\
\hline
\end{tabular}

Pengaruh nilai perubahan \%PO terhadap $t_{d}$ dan $\tau_{p}$ disajikan dalam Gambar 6. Dalam gambar tersebut, terlihat bahwa semakin besar nilai perubahan $\%$ PO nilai $t_{d}$ semakin besar. Perubahan \%PO yang besar menyebabkan sistem di tangki netralisasi lebih lambat merespon, akan tetapi membutuhkan waktu yang lebih singkat untuk mencapai kondisi steady state kembali. Waktu yang lebih singkat 
tersebut ditunjukkan dengan berkurangnya $\tau_{\mathrm{p}}$ dengan bertambahnya nilai perubahan \% PO.

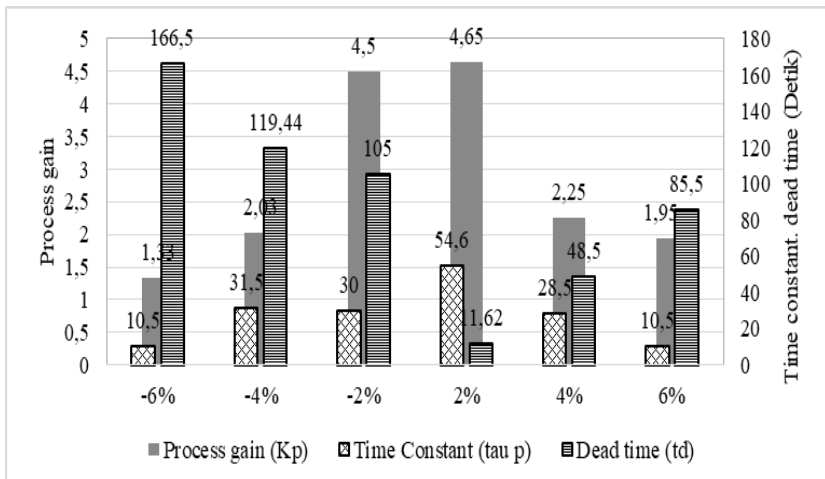

Gambar 6. Perbandingan nilai dead time $\left(\mathrm{t}_{\mathrm{d}}\right)$ dan time constant process $\left(\tau_{\mathrm{p}}\right)$ pada Berbagai Nilai Perubahan $\%$ PO.

Gambar 6 juga menunjukkan bahwa untuk perubahan $\%$ PO yang bernilai negatif ternyata menyebabkan keterlambatan respon $\left(\mathrm{t}_{\mathrm{d}}\right)$ yang lebih besar daripada ketika perubahan \%PO bernilai positif. Kondisi ini dikarenakan perubahan \%PO bernilai positif memberi dampak semakin besarnya laju alir kapur (lime) yang ditambahkan ke dalam tangki netralisasi. Penambahan laju alir kapur berdampak dengan cepat terhadap $\mathrm{pH}$ larutan di tangki netralisasi. Sedangkan ketika perubahan \%PO bernilai negatif, menunjukkan bahwa laju alir kapur (lime) yang ditambhakan ke dalam tangki netralisasi dikurangi. Pengurangan laju alir kapur ini berdampak lambat, karena $\mathrm{pH}$ influent yang bersifat sangat basa lebih dominan.

\subsection{Tuning dengan metode Cohen - Coon.}

Hasil perhitungan parameter PID dengan tuning metode Cohen - Coon disajikan di Tabel 3. Metode Cohen - Coon dipilih berdasarkan hasil penelitian (Babu \& Swarnalath, 2017) yang menyatakan bhwa tuning metode Cohen - Coon memberikan nilai overshoot minimal, walaupun membutuhkan settling time yang lebih lama daripada metode Ziegler Nichols. Metode Ziegler Nichols tidak dapat diaplikasikan di unit QIC 3001 karena proses pengendalian di unit QIC 3001 mempunyai nilai waktu keterlambatan $\left(t_{d}\right)$ yang sangat besar. Bingi (2016), menyatakan bahwa tuning metode Ziegler Nichols memberikan hasil yang kurang memuaskan apabila diterapkan pada sistem dengan perubahan set point (servo system) yang memiliki waktu keterlambatan besar $\left(\mathrm{t}_{\mathrm{d}}\right)$.

Hasil tuning metode Cohen - Coon diaplikasikan di sistem pengendali QIC 3001 yang terdapat di tangki netralisasi unit pengolah limbah. Sebagai pembanding, simulasi sistem pengendali QIC 3001 dengan Matlab juga dilakukan. Contoh diagram blok yang digunakan untuk menggambar-kan proses di pengendali QIC 3001 disajikan di Gambar 7.

Perbandingan hasil aplikasi di plant dan hasil simulasi untuk masing-masing perubahan \%PO disajikan di Gambar 8. Hasil tuning diaplikasikan untuk set point tetap atau dengan perubahan disturbance berupa $\mathrm{pH}$ influent pada tangki netralisasi. Masing-masing parameter hasil tuning diaplikasikan langsung ke lapangan melalui Distribution Control System Room (DCS Room).

Tabel 3. Hasil Perhitungan Parameter PID dengan Tuning Metode Cohen

\begin{tabular}{|c|c|c|c|c|}
\hline $\begin{array}{c}\text { Gambar } \\
\text { No. }\end{array}$ & $\begin{array}{c}\text { Perubahan } \\
\% \text { PO }\end{array}$ & $\begin{array}{c}\text { Controler } \\
\text { gain Kc }\end{array}$ & $\begin{array}{l}\text { Integral } \\
\quad \text { time } \\
\tau_{\mathrm{i}}(\text { detik })\end{array}$ & $\begin{array}{c}\text { Derivative } \\
\text { time } \\
\tau_{\mathrm{d}} \text { (detik) }\end{array}$ \\
\hline 5. (a) & $\begin{array}{c}20-26 \\
(+6 \%)\end{array}$ & 0.212 & 88,47 & 12.53 \\
\hline 5. (b) & $\begin{array}{c}20-24 \\
(+4 \%)\end{array}$ & 0.459 & 76,92 & 13.47 \\
\hline 5. (c) & $\begin{array}{c}20-22 \\
(+2 \%)\end{array}$ & 1,401 & 26,3 & 4,07 \\
\hline 5. (d) & $\begin{array}{c}26-20 \\
(-6 \%)\end{array}$ & 0.251 & 151,36 & 15.59 \\
\hline 5. (e) & $\begin{array}{c}24-20 \\
(-4 \%)\end{array}$ & 0.296 & 150,90 & 25,71 \\
\hline 5. (f) & $\begin{array}{c}20-18 \\
(-2 \%)\end{array}$ & 0.140 & 135,73 & 23,33 \\
\hline
\end{tabular}

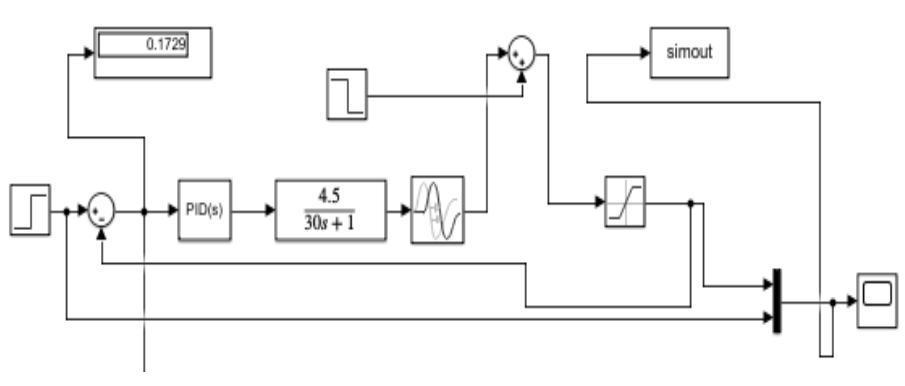

Gambar 7. Diagram blok sistem pengendali pH di Unit QIC 3001.

Aplikasi di plant memberikan hasil yang cukup jauh berbeda dengan simulasi. Hasil simulasi (yang ditunjukkan dengan garis berupa titik - titik terputus pada Gambar 8) menunjukkan bahwa respon dapat kembali ke set point ketika ada perubahan disturbance, untuk semua data fungsi hantar. Akan tetapi aplikasi di plant menunjukkan bahwa selama proses (600 detik) sistem belum ada yang dapat kembali ke set point.

Semua kurva respon menunjukkan hasil yang osilatif, tetapi dengan period of oscilation yang lebih besar daripada kondisi sebelum dilakuan tuning, seperti terlihat pada Gambar 9. Hal ini dikarenakan sistem pengendali di unit QIC 3001 memiliki waktu keterlambatan $\left(t_{d}\right)$ yang sangat besar. Rice (2010) menyatakan bahwa semakin besar waktu keterlambatan proses, relatif terhadap time contant proses, semakin sulit proses dikendalikan. Biasanya, ketika waktu keterlambatan proses (Dead-Time process) melebihi Time Constant, kecepatan pengendali untuk merespon perubahan yang diberikan berkurang secara signifikan. Hal itu akan merusak kemampuan pengontrol PID untuk menjaga stabilitas (Rice, 2010). Semakin besarnya nilai period of oscillation diharapkan dapat menurunkan frekuensi osilasi yang terjadi sehingga sistem dapat kembali ke set point. 

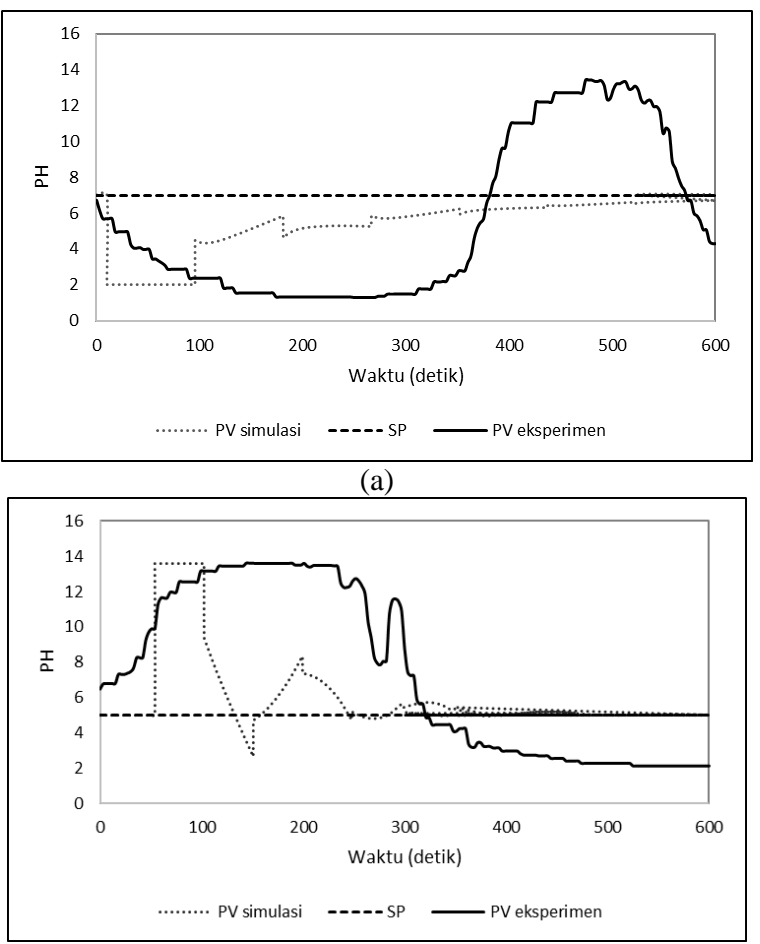

(b)

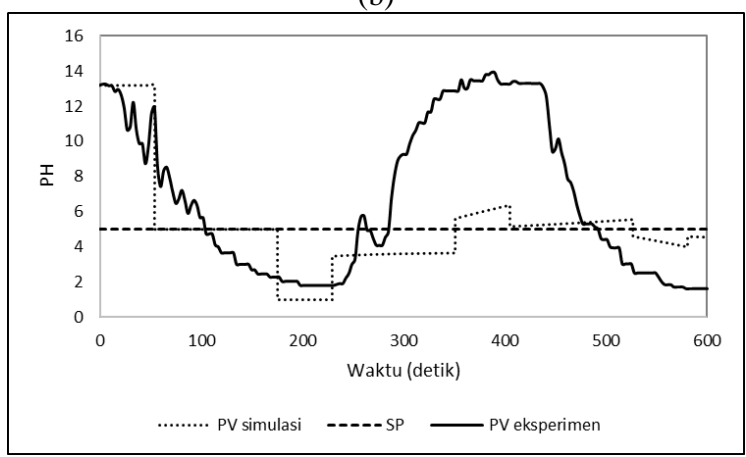

(c)

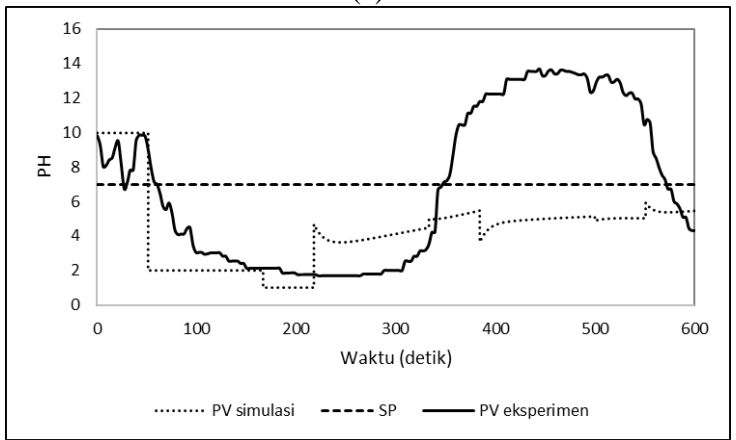

(d)

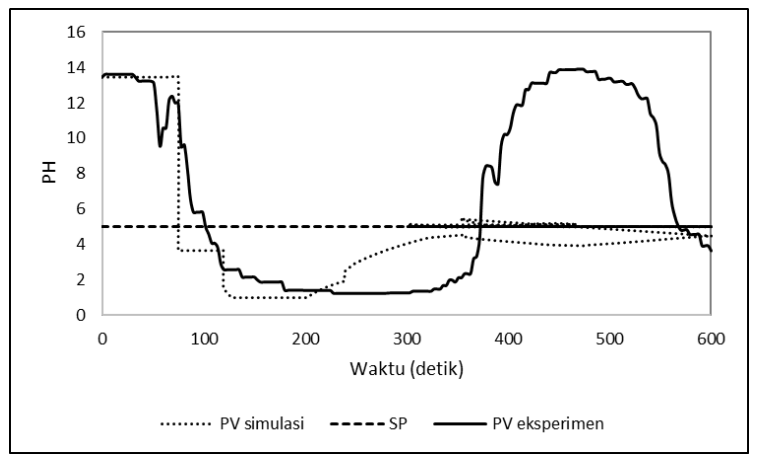

(e)

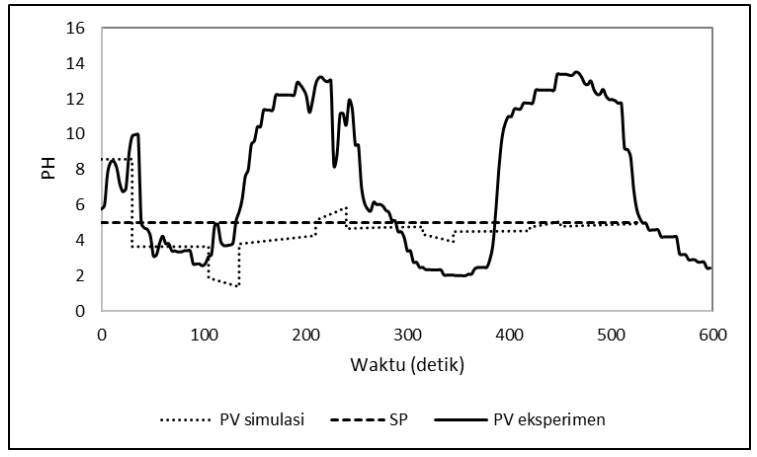

(f)

Gambar 8. Kurva Respon Aplikasi Parameter Hasil Tuning di Unit QIC 3001 serta Hasil Simulasi Uuntuk Masing-Masing Fungsi Hantar dengan Perubahan $\%$ PO (a) $+6 \%$, (b) $-6 \%$, (c) $+4 \%$, (d) $-4 \%$, (e) $+2 \%$ dan (f) $-2 \%$.

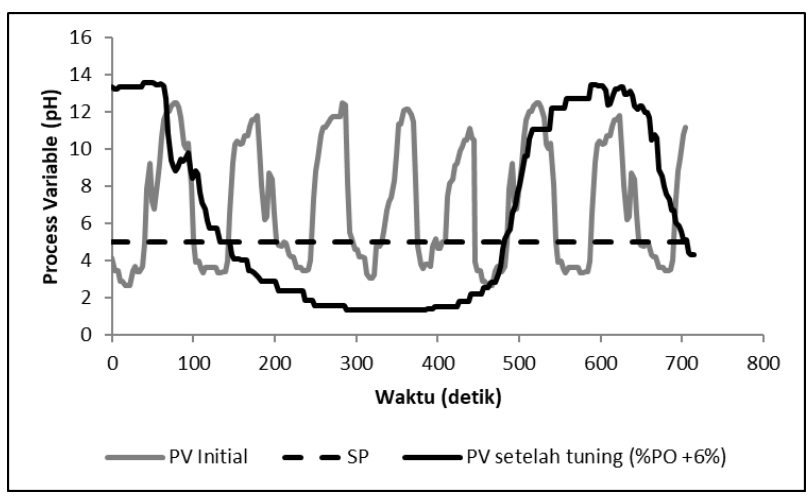

Gambar 9. Perbandingan Kurva Respon Sebelum Dilakukan Tuning (PV Initial) dengan Kurva Respon Setelah Dilakukan Tuning (PV Setelah Tuning)

Analisa respon tuning dilakukan untuk melihat respon terbaik dari hasil tuning PID dengan rentang waktu sebesar 600 detik atau selama 10 menit tiap percobaan untuk kurva respon yang diperoleh dari hasil aplikasi di plant. Analisa dilakukan dengan menghitung nilai overshoot, settling time, period of oscillation dan sum squared of error (SSE). Hasil analisa respon tuning disajikan di Tabel 4. Nilai settling time tidak dapat dihitung karena semua respon hasil tuning masih tidak jauh berbeda dengan data initial. Hal ini menunjukkan bahwa kondisi osilatif masih berlangsung, akan tetapi period of oscillation yang timbul lebih besar. Dengan demikian perlu dicoba metode tuning lain yang dapat mengakomodasi 
adanya waktu keterlambatan yang cukup besar dalam pengendalian pH di Unit QIC 3001.

Tabel 4. Hasil Analisa Respon Hasil Tuning Metode Cohen - Coon

\begin{tabular}{lcccc}
\hline $\begin{array}{c}\text { Gambar } \\
\text { No. }\end{array}$ & $\begin{array}{c}\text { Perubahan } \\
\text { \%PO }\end{array}$ & $\begin{array}{c}\text { Overshoot } \\
\text { OS }\end{array}$ & $\begin{array}{c}\text { Period of } \\
\text { Oscillation } \\
\text { P (detik) }\end{array}$ & SSE \\
\hline 8. (a) & $\begin{array}{c}20-26 \\
(+6 \%)\end{array}$ & 0,9376 & 570 & 5394,8 \\
8. (b) & $\begin{array}{c}20-24 \\
(+4 \%)\end{array}$ & 1,7206 & 305 & 5494,3 \\
8. (c) & $\begin{array}{c}20-22 \\
(+2 \%)\end{array}$ & 1,7827 & 389 & 4619,4 \\
8. (d) & $\begin{array}{c}26-20 \\
(-6 \%)\end{array}$ & 0,9575 & 409 & 3501,4 \\
8. (e) & $\begin{array}{c}24-20 \\
(-4 \%)\end{array}$ & 1,7806 & 465 & 5984,1 \\
8. (f) & $\begin{array}{c}20-18 \\
(-2 \%)\end{array}$ & 1,7028 & 296 & 4320,4 \\
9 (initial & - & 1,4952 & 102 & - \\
cond.) & & & & \\
\hline
\end{tabular}

\section{Kesimpulan}

Hasil step test untuk mendapatkan fungsi hantar menunjukkan bahwa sistem pengendali di QIC 3001 memiliki waktu keterlambatan (dead time) yang lebih besar daripada time constant process.

Hasil tuning yang diaplikasikan di unit QIC 3001 menunjukkan bahwa semua parameter pengendali PID yang digunakan masih menghasilkan respon yang osilatif, tetapi dengan frekuensi osilasi yang semakin berkurang. Hasil terbaik diperoleh untuk hasil tuning berdasarkan fungsi hantar yang diperoleh dengan memberikan perubahan PO sebesar -6\% (dari \%PO 26\% menjadi 20\%). Parameter pengendali PID yang diperoleh adalah $K_{\mathrm{c}}=0,251 ; \tau_{\mathrm{i}}=$ 151,36 detik dan $\tau_{\mathrm{D}}=12,53$ detik.

Performa respon dengan parameter pengendali tersebut memiliki nilai overshoot terendah, yaitu 0,9575, dan sum squared of error terkecil, yaitu 3501,377. Akan tetapi nilai period of oscillation masih besar (570 detik) sehingga perlu dicoba metode tuning lain, khususnya yang dapat mengakomodasi adanya waktu keterlambatan yang lebih besar daripada time constant process. Selain itu, dapat dilakukan metode pengendalian lanjut, antara lain dengan menggunakan Smith Predictor.

\section{Daftar Pustaka}

Babu, R., \& Swarnalath, R, 2017, Comparison of Different Tuning Methods for $\mathrm{pH}$ Neutralization in Textile Industry. Journal of Applied Sciences, 17(3), pp. 142147. https://doi.org/10.3923/jas.2017.142.147

Hermawan, Y. D., 2010, Implementation of Process Reaction Curve for Tuning of Temperature Control Parameters in A 10 L Stirred Tank Heater, Journal of Materials Science and Engineering A 1 (2011). pp.572-577. ISSN 1934-89591-6.

Hermawan, Y. and G. Haryono, 2012, Dynamic Simulation
And Composition Control In A 10 L Mixing Tank. Reaktor, 14(2), pp. 95-100, https://doi.org/10.14710/reaktor.14.2.95-100

Kumar, D. D., \& Deepika, D., 2014, Performance comparison of $\mathrm{pH}$ Neutralization process among different tunings of conventional controllers. Applied Mechanics and Materials 573, pp. 260-266. https://doi.org/10.4028/www.scientific.net /AMM.573.260

Rice, R. C., 2010, PID Tuning Guide A Best-Practices Approach to Understanding and Tuning PID Controllers First Edition Simplifying PID Control, Optimizing Plant Performance. Retrieved from https://web-material3.yokogawa.com/Yokogawa_ PID_Tuning_Guide_-_csTuner.pdf?_ga=1.61113583 .296607337 .1493113296

Wahid, A., \& Abdillah, F., 2014, Pengendalian pH Limbah Cair Laboratorium Departemen Teknik Kimia UI Menggunakan Pengendali PID Linear Pada Mini Plant WA921. SINERGI 18(2), pp. 85-91. 